\title{
KEBERADAAN PENGETAHUAN LOKAL MASYARAKAT TANI DI ERA REVOLUSI HIJAU (STUDI KASUS PETANI PADI DI DESA CAREBBU KECAMATAN AWANGPONE KABUPATEN BONE PROVINSI SULAWESI SELATAN)
}

\author{
The Existence of Indigenous Knowledge of The Peasant Society in The Era of Green \\ Revolution \\ (Case Study of Paddy Rice Farmers in The Village of Carebbu, Awangpone Sub District, \\ Bone Regency, South Sulawesi Province)
}

\author{
Andi Anizha Rahmadani, Tamzil Ibrahim*, Sa'adah, Yopie Lumoindong, Eymal \\ Demmallino \\ Program Studi Agribisnis, Departemen Sosial Ekonomi Pertanian, Fakultas \\ Pertanian, Universitas Hasanuddin, Makassar \\ *Kontak penulis: ramadhanianizha@yahoo.com
}

\begin{abstract}
This study aims to analyze the existence of indigenous knowledge of peasant society on farming management especially of rice land farming in The Village of Carebbu, Awangpone Subdistrict, Bone Regency, South Sulawesi Province during April 2019. The method used in this study is descriptive qualitative and case study method with a sampling technique that used is purposive sampling and snowball sampling. Researcher use is an in-depth interview and analyzed by qualitative data analysis with the approach of the AGIL functional theory of Talcott Parson. This result shows if there is 8 indigenous knowledge that exists on peasant society from generation to generation on their farming management of paddy rice land, but in the middle of the green revolution, it shows that indigenous knowledge of peasant society is lost some, there are 2 of 8 indigenous knowledge has to begin to be left out. This is due to the thinking of the peasant society which began to change from irrational to rational.
\end{abstract}

Key Words: Indigenous knowledge; farm society; green revolution.

\begin{abstract}
Abstrak
Penelitian ini bertujuan untuk menganalisis keberadaan sistem pengetahuan lokal masyarakat tani dalam pengelolaan usahatani khususnya pada usahatani padi sawah yang dilakukan di Desa Carebbu, Kecamatan Awangpone, Kabupaten Bone pada tahun 2019. Penelitian ini menggunakan pendekatan deskriptif kualitatif dan metode studi kasus dengan pengambilan informan secara purposive dan snowball. Pengumpulan data dilakukan tiga tahap, yaitu obeservasi, wawancara mendalam, dan dokumentasi. Data dianalisis secara kualitatif dengan pendekatan teori fungsional AGIL Talcott Parson. Hasil penelitian menunjukkan bahwa terdapat delapan bentuk pengetahuan lokal yang dilakukan oleh masyarakat tani secara turun temurun dalam mengelola usahatani padi sawah, namun di tengah maraknya revolusi hijau terlihat bahwa pengetahuan lokal masyarakat tani telah mulai ditinggalkan, yaitu dua dari delapan bentuk pengetahuan lokal yang ada telah mulai ditinggalkan. Hal ini dikarenakan oleh pemikiran masyarakat tani yang mulai rasional instrumental.
\end{abstract}

Kata Kunci: pengetahuan lokal; masyarakat tani; revolusi hijau.

Sitasi: Rahmadani A.A., Ibrahim T., Sa'adah. Lumoindong E., Demmallino E.B. 2020. Keberadaan Pengetahuan Lokal Masyarakat Tani di Era Revolusi Hijau (Studi Kasus Petani Padi di Desa Carebbu, Kecamatan Awangpone, Kabupaten Bone). JSEP 16(2): 149 - 160. 


\section{Pendahuluan}

Manusia (terutama masyarakat) mempunyai hubungan yang erat dengan kebudayaan karena segala sesuatu yang terdapat di dalam masyarakat ditentukan adanya oleh kebudayaan yang dimiliki oleh masyarakat itu (Koentjaraningrat, 2009). Kebudayaan turun temurun dari generasi ke generasi dan tetap hidup walaupun manusia yang menjadi anggota masyarakat sudah berganti karena kelahiran dan kematian (Mappangaja, 2009).

Pertanian (agriculture) merupakan hasil dari suatu kebudayaan yang sudah diwariskan turun-temurun oleh nenek moyang kepada generasi berikutnya (Wolf, 1985). Kebudayaan kaitannya dengan pertanian adalah segala aktivitas masyarakat yang memberikan ciri-ciri khusus mengenai kehidupan masyarakat yang dalam hubungannya adalah menyangkut cara mengelola lahan pertanian, ritual, peralatan yang digunakan hingga segala kegiatan yang berhubungan langsung dengan kegiatan menanam dan memanen hasil pertanian (Kamaluddin et.al, 2012; Syahruni, 2014).

Sejarah dunia pertanian mengalami lompatan yang sangat berarti, dari pertanian tradisional menuju pertanian modern. Hal ini ditandai dengan dimulainya revolusi di bidang pertanian atau revolusi hijau. Revolusi hijau yang marak dicanangkan oleh pemerintah tahun 1970-an demi pertumbuhan ekonomi dengan dalih peningkatan kapasitas produksi dan kesejahteraan masyarakat, maka revolusi hijau ini masuk ke pola pengolahan pertanian (Salman, 2012)

Sulawesi Selatan merupakan salah satu provinsi di Indonesia yang memiliki beragam budaya dan merupakan daerah penghasil tanaman pangan terbesar di Kawasan Timur Indonesia dengan luas areal pertanian 653.950,5 Ha. Salah satu kabupaten yang memiliki pertanian padi dengan beragam kearifannya adalah Kabupaten Bone dengan luas lahan padi pada tahun 2017 seluas 112.968,3 Ha (Badan Pusat Statistik, 2017).

Desa Carebbu merupakan salah satu desa yang terdapat di Kecamtan Awangpone yang sebagian masih menerapkan pengetahuan lokalnya dalam usahatani padi sawah dengan luas areal tanaman seluas 250,75 Ha. Dalam budidaya padi masih banyak pengetahuan lokal yang belum diketahui banyak orang, baik itu pengetahuan lokal yang dahulu pernah ada maupun pengetahuan lokal yang saat ini mulai hilang dikarenakan maraknya revolusi hijau. Selama revolusi hijau memang telah terjadi kontestasi pengetahuan antara pengetahuan asli dalam kebudayaan petani dengan pengetahuan modern yang datang dari luar (Berkes et al, 1995; Ali, 2000; Basry, 2012; Husnah et al, 2015). Penelitian ini bertujuan menggambarkan eksistensi pengetahuan lokal selama proses revolusi hijau.

\section{Metode Penelitian}

Penelitian ini dilaksanakan di Desa Carebbu Kecamatan Awangpone Kabupaten Bone Provinsi Sulawesi Selatan. Pemilihan lokasi penelitian dilakukan secara sengaja (purposive sampling) dengan alasan pada desa ini berlangsung kontestasi antara pengetahuan lokal dengan pengetahuan modern dalam praktek pertanian. Penelitian dilaksanakan tahun 2019.

Pengambilan sampel dilakukan secara sengaja (purposive sampling) yaitu pengambilan sampel sumber data dengan pertimbangan tertentu serta dilakukan 
secara snowball sampling yaitu pengambilan sampel sumber data yang pada awalnya jumlahnya sedikit dan dilanjutkan dengan sumber data lainnya hingga data dianggap cukup (Sugiono,2008). Peneliti melakukan wawancara mendalam, yakni proses tanya jawab sambil bertatap muka antara peneliti dengan informan tanpa menggunakan pedoman wawancara.

Analisis data kualitatif digunakan berbasis teori fungsional AGIL dari Parson. Teori fungsional AGIL menjelaskan empat fungsi, (Ritzer, 2007) (1) Adaptation, sistem sosial harus mampu menyesuaikan diri dengan lingkungan yang dihadapi; (2) Goal Attainment, tujuan individu harus menyesuaikan dengan tujuan sosial yang lebih besar agar tidak bertentangan dengan tujuan-tujuan lingkungan sosial; (3) Integration, menunjukkan adanya solidaritas sosial dari bagian-bagian yang membentuknya, serta berperannya masing-masing unsur tersebut sesuai dengan posisinya, sehingga terbangun integrasi; dan (4) Latent Pattern Maintenance, pemeliharaan pola yang tersembunyi, yang biasanya berwujud sistem nilai budaya yang selalu mengontrol tindakan-tindakan individu.

Pengetahuan lokal diidentifikasi terkait aktivitas hulu, on-farm dan hilir dari sistem pertanian yang berjalan. Pengetahuan lokal tersebut dihubungkan dengan aspek penting dari revolusi hijau yakni penggunaan bibit unggul, pengolahan lahan yang baik, pengairan yang teratur dan pemupukan. Kontestasi pengetahuan lokal dengan pengetahuan modern dipetakan pada aspek-aspek tersebut, untuk kemudian dinalisis sampai mana tetap berjalan fungsi AGIL dalam sistem pertanian tersebut.

\section{Hasil dan Pembahasan}

\subsection{Sistem Pengetahuan Lokal dan Pengelolaan Usahatani}

Sistem pengetahuan lokal adalah praktik-praktik usahatani yang dilakukan oleh masyarakat Desa Carebbu dalam melakukan kegiatan bertani yang sudah menjadi kebiasaan turun temurun dan sudah dilakukan sejak lama. Terdapat beberapa praktik-praktik usahatani yang dilakukan dalam bertani padi sawah, mulai dari persiapan tanam sampai pasca panen dengan uraian sebagai berikut.

Mattanra Esso (Penentuan Hari Baik). Kegiatan ini merupakan awal dari segala sistem pengetahuan lokal yang dilakukan dalam berusahatani padi sawah. Mattanra Esso dilakukan oleh pimpinan spiritual kampung yang dipercaya oleh masyarakat setempat dan berasal dari keturunan asli daerah ini yang disebut Sanro Wanua. Sanro Wanua memiliki sebuah pemahaman spiritual atau ilmu ketauhidan yang disebut Pарріјерри. Рарріjерри sering dihubungkan dengan pemahaman ilmu tasawwuf. Pappijeppu digunakan sebagai sumber informasi/petunjuk untuk melakukan segala hal di Desa Carebbu. Sanro Wanua dengan pappijeppunya yang memberi nasehat tentang hari baik memulai pengolahan tanah, penanaman benih yang pertama, dan sebagainya.

Ma'doja Bine. Dalam bahasa Bugis berarti begadang untuk benih padi, ia adalah ritual yang dilangsungkan menjelang menurunkan benih padi di sawah. Ma'doja Bine dilakukan saat Sanro Wanua telah menentukan hari yang baik melalu pappijeppu. Rangkaian ritual ma'doja bine dimulai dari Mappalece Bine, Mappangolo, Massure', hingga ritual Mappasili. Mappalece Bine (Merayu Benih) dalam bentuk masyarakat memberikan seserahan yang berupa cermin (camming), sisir (jakka), bedak (bedda'), lipstik (gincu/dencong), dan cilla'. Hal ini 
bermakna bahwa masyarakat meyakini jikalau dewi padi (Sangiang Serrie) berwujud perempuan sehingga hal ini dilakukan sebagai alat untuk merayu agar benih yang akan ditanam akan sesuai dengan harapan petani. Mappangolo (Berdo'a) Mappangolo merupakan salah satu warisan leluhur masyarakat yang masih dipegang teguh hingga saat ini. Tujuan diadakannya prosesi atau ritual tersebut adalah untuk memohon keselamatan. Dalam hal pertanian padi sawah ritual ini bertujuan untuk memohon keselamatan bagi tanaman padi agar terhindar dari hama dan penyakit yang dapat merusak sehingga menyebabkan kekurangan bahkan kehilangan hasil panen. Selain itu, ritual ini juga bertujuan untuk memohon keselamatan bagi petani agar terhindar dari bahaya selama melakukan kegiatan bertani. Dalam pelaksanaannya, ritual ini dilakukan oleh bissu (pendeta agama tradisional orang Bugis) dan Sanro Wanua.

Adapun bacaan doa saat melakukan ritual mappangolo (berdoa) adalah:

“Bissmilahirrahmanirrahim. Dupa alusu kutunu, alusu kupattunuang, alusu kulettui, alusu mappalettu. Natarima alusu na pakkasiwianna attanna Puang Allahu Ta'ala sininna lise' wanuae lao ri ajoarengkku Sangiang Serrie na natarimai barakka'na pole ri Puang Allahu Ta'ala sininna pa'banuae. Barakka Lailaha Illallah. Alfatihah"

Artinya:

"Bissmilahirrahmanirrahim (dengan menyebut nama Allah yang Maha Pengasih lagi Maha Penyayang). Saya berdoa, ikhlas kupanjatkan, Sang Pencipta yang kutujukan, malaikat yang menyampaikan. Diterimalah persembahan manusia ciptaan Allah SWT dari seluruh isi kampong kepada tuan ku Sangiang Serrie (Dewi Padi) sehingga kami menerima berkah dari Allah SWT.Berkah Lailaha Illallah (tiada Tuhan selain Allah). Alfatihah (surah pembuka). (AmboTone,2019)

Doa yang dipanjatkan tersebut bermakna keikhlasan yang ditujukan kepada Allah SWT yang disampaikan oleh malaikat agar kiranya segala persembahan masyarakat dalam kampung ini akan diperuntukkan kepada Dewi Padi yang merupakan utusan Dewata Seuwwae untuk memberi kehidupan kepada orang-orang bumi dengan harapan agar segala kegiatannya dalam bertani dapat diberkahi dan terhindar dari segala masalah khususnya pada tanamannya agar menghasilkan sesuai harapan mereka. Massure' (Pembacaan Surat). Massure' yaitu pembacaan Sure' La Galigo (sebuah karya sastra, dengan satuan kaki matra berupa lima atau empat suku kata membentuk larik, yang menceritakan kisah asal usul atau proses awal keberadaan manusia Bugis di dunia) (Sulkarnaen, 2017). Sure' yang sering dibaca yaitu Sure' Riulo'na Batara Guru ri Lino yang berkisah mengenai mula tau, asal usul kedatangan manusia keturunan dewa, yakni Batara Guru sebagai manusia pertama di dunia dan Sureq Meong Paloe Karellae, yang menceritakan pengembaraan Sangiang Serri yang ditemani oleh kucing belang tiga warna, sang pengawal setianya. Sangiang Serri mempersyaratkan untuk bersedia tinggal di suatu daerah, yang berciri penduduknya harus hidup rukun dan damai, suka bekerja keras, mempunyai etika, selalu memuliakan dan berseru kepada Dewata (Patotoe) sebagai sang pencipta. Ritual ini didendangkan oleh Sanro Wanua dan bissu. Dalam hal pertanian padi sawah, ritual ini dilaksanakan untuk memberikan pemahaman kepada masyarakat mengenai asal usul padi yang dititipkan oleh Sang Pencipta untuk kemaslahatan ummat. Mappasili (Pensucian). Makna dari ritual ini adalah untuk membersihkan serta menyucikan benih yang akan ditanam sehingga terhindar dari malapetaka/ 
bencana agar dapat memperoleh hasil yang maksimal sesuai yang diinginkan para petani. Ritual ini dilakukan langsung oleh Sanro Wanua dengan menggunakan daun sirih dan daun tawa serta air dalam sebuah wadah yang telah didoakan saat melakukan mappangolo (berdoa). Sanro Wanua akan memercikkan air kepada benih yang akan ditanam dengan menggunakan daun sirih dan daun tawa dengan membaca basmalah.

Mappanguju bine (Mempersiapkan Benih). Ritual mappanguju bine diawali dengan proses mademme bine (perendaman benih) yang dilakukan selama 2 hari 2 malam di dalam baskom besar. Hal ini dilakukan untuk mempercepat perkecambahan benih dan memisahkan antara benih yang berkualitas dan benih yang kurang berkualitas. Setelah benih direndam, maka tahap selanjutnya adalah ammile bine (memilih benih) yang berarti proses penyeleksian benih yang akan dibudidayakan di sawah karena hasil produksi padi sangat bergantung pada kualitas benih yang ditanam. Setelah melakukan penyeleksian benih, maka benih tersebut akan dimasukkan ke wadah yang dilapisi kain putih. Kain putih ini bermakna kesucian.

Mangampo Bine (Menabur Benih). Dalam kegiatan penyemaian benih, petani di Desa Carebbu, Kecamatan Awangpone, Kabupaten Bone masih menggunakan sistem tanam pindah (tapin) sebagai warisan leluhur dalam bertanam padi. Proses penyemaian diawali dengan ritual mangampo bine (menabur benih) di lahan yang telah disiapkan. Cara yang digunakan hampir sama dengan yang dilakukan oleh petani pada umumnya. Sebelum menggarap tanah untuk penyemaian, maka dilakukan mappassili galung abbineng (penyucian lahan penyemaian) terlebih dahulu. Cara yang dilakukan saat penyucian lahan penyemaian sama halnya dengan cara melakukan penyucian benih. Hal ini bertujuan agar lahan tersebut dapat mengasilkan bibit yang baik dan berkualitas. Ritual mangampo bine (menabur benih) dilakukan sambil menghadap ke arah barat, dimana arah barat merupakan arah kiblat umat Islam dalam mendirikan Shalat. adalah:

Adapun bacaan doa saat melakukan ritual mangampo bine (menabur benih)

"Bismillahirrahmanirrahim. Ikung. Iyakkung. Iyakking. Tasisseng tassiajeppui. Aja tasissolangngi. Barakkallailahaillallah" Artinya:

“Bismillahirrahmanirrahim (dengan menyebut nama Allah yang Maha Pengasih lagi Maha Penyayang). Tanah. Manusia. Langit. Kita saling mengenal kita saling memahami. Jangan kita saling merusak. Barakallailahaillallah" (Ambo Tone, 2019)

Adapun doa yang dipanjatkan tersebut tersirat adanya sebuah pengharapan agar benih yang akan disemaikan akan menghasilkan hasil yang baik. Manusia dan alam semesta haruslah saling memahami dan menghargai tanpa harus saling merusak.

Massisi Bine (Menanam Bibit). Ini merupakan kegiatan menanam bibit dengan menancapkan beberapa batang bibit padi. Jumlah bibit padi yang disisipkan sekitar 3-5 batang. Adapun bacaan doa saat akan melakukan ritual massisi bine (menanam bibit) adalah:

"Bismillahirrahmanirrahim. Wakkatta pasisi $i$ bine Sangiang Serrie na walai pangampe tubu na uwakkamalakeng lao ri padapadakku na saba' Allah Ta'ala" 
Artinya:

"Bismillahirrahmanirrahim (dengan menyebut nama Allah yang Maha Pengasih lagi Maha Penyayang). Saya niatkan menanam bibit padi ini dari Sangiang Serri agar menjadi berkah pada tubuhku dan ku amalkan pada sesama ku karena Allah SWT" (Ambo Tone, 2019)

Adapun doa yang dipanjatkan tersirat makna bahwa bibit padi hasil penyiangan berasal dari Sangiang Serrie sehingga akan tumbuh dengan baik tanpa masalah sesuai dengan harapan. Serta hasilnya nanti telah diniatkan oleh petani agar menjadi berkah ketika masuk ditubuhnya dan dapat berbagi dengan sesamanya sebagai bentuk amalan.

Mappalece Ase Lunrara (Merayu Padi Hamil). Mappalece ase lunrara adalah ritual yang dilakukan pada saat batang padi telah hamil. Ritual ini dilakukan dengan mangusapkan sejumput tanah ke batang padi yang sudah hamil (ase lunrara) dengan gerakan dari bawah ke atas sambil mengucapkan doa. Makna mengusap ase lunrara dengan gerakan dari bawah ke atas adalah memohon harapan agar cepat mengeluarkan bakal buah (mpesso). Adapun bacaan doa saat melakukan ritual mappalece ase lunrara (merayu padi hamil) adalah:

“Tenna podo madeceng cokkomu na mabarakka ri pada-padakku saba' Allah Ta'ala"

Artinya:

"Semoga kau tumbuh dengan baik agar menjadi berkah bagi semua umat manusia karena Allah SWT". (Ambo Tone, 2019)

Adapun doa yang dipanjatkan tersirat makna bahwa keinginan sang petani agar batang padi yang sedang hamil tersebut nantinya akan terus tumbuh dengan baik dan menghasilkan padi yang baik pula, sehingga akan menjadi berkah dari Allah SWT.

Mangala (Panen). Kegiatan panen tidak boleh dilakukan sembarangan. Sehari sebelum diadakan panen, Sanro Wanua akan mengelilingi sawah dalam lingkup Desa Carebbu. Hal ini dilakukan untuk melihat keadaan padi yang akan dipanen. Ketika padi sudah menguning dan telah mengeluarkan bakal buah (mpesso) maka ini menandakan padi telah siap dipanen. Maka Sanro Wanua akan mengikat segenggam padi dengan daun use' dengan harapan padi tersebut akan mause' (padat dan berisi). Proses panen ini akan dilakukan terlebih dahulu oleh Sanro Wanua sebagai pakkaramula, barulah kemudian dilanjutkan oleh masing-masing petani untuk melakukan panen. Panen dilakukan dengan menggunakan alat yang dinamakan rakkapeng (anai-anai). Adapun bacaan doa saat melakukan ritual panen adalah:

"Bismillahirrahmanirrahim. Ku tarimani resoku. Engka to ri aleku, engka to ripadapadakku. Engka to ku anre, engka to ku balu"

Artinya:

"Bismillahirrahmanirrahim (dengan menyebut nama Allah yang Maha Pengasih lagi Maha Penyayang). Saya telah menerima hasilnya. Ada di diriku, ada pula sama orang lain. Cukup saya makan, dan cukup pula saya jual". (Ambo Tone, 2019).

Dari doa tersebut bermakna bahwa rezeki yang diterima oleh petani yang berupa hasil panen bukan hanya milik mereka secara keseluruhan melainkan sebagian dari hasil panennya tersebut ada hak-hak yang mesti diberikan kepada orang lain. Dalam artian bahwa seseorang hidup di dunia ini merupakan makhluk sosial yang tidak bisa hidup tanpa orang lain, dan tidak bisa hidup secara individu 
tanpa bantuan dari orang lain. Meskipun secara langsung beras tersebut dijual, namun hal tersebut diartikan untuk membantu orang lain, orang yang membelipun pasti karena mereka membutuhkannya.

Mappadekko (Pesta Panen). Mappadekko merupakan adat masyarakat bugis sejak dahulu kala hingga saat ini, yang terus-menerus dipertahankan sebagai wujud penghormatan terhadap leluhur. Waktu pelaksanaanya harus mengikuti tradisi yaitu setelah musim panen dan memasuki musim kemarau di malam hari. Alasan mengapa pesta adat mappadekko dilaksanakan di malam hari adalah mengikuti tradisi nenek moyang serta tidak adanya aktivitas bertani di malam hari. Selain waktu yang telah ditentukan, pakaian pemain dalam pesta tersebut juga ditentukan yaitu baju adat suku bugis, alasannya sederhana yaitu ketika masyarakat mengadakan pesta adat maka harus pula mengenakan pakaian adat. Selanjutnya tata cara pelaksanaan pesta adat mappadekko adalah pemain perempuan berjumlah empat orang sedangkan laki- laki berjumlah tiga orang, memiliki tugasnya masingmasing yaitu memadukan irama tumbukan alu pada palungeng dan alat musik yang digunakan serta memadukan tarian-tarian atau atraksi-atraksi yang dipertontonkan. Selain menumbukkan alu pada palungeng, pemain harus menumbuk padi sampai selesai dan berakhirlah pesta adat mappadekko yang ditutup dengan makan malam bersama seluruh masyarakat yang hadir. Adapun makna pesta adat mappadekko tersebut bagi masyarakat Desa Carebbu adalah rasa syukur terhadap Tuhan atas berkah dan limpahan rezeki berupa padi yang telah mereka panen. Selain itu bagi masyarakat Desa Carebbu pesta adat tersebut adalah doa kepada Tuhan agar panen yang akan datang bisa lebih baik lagi dan dapat berkumpul kembali ke dalam pesta adat mappadekko. Di dalam proses pelaksanaan pesta adat mappadekko ada nilai-nilai yang tekandung dan terus dijaga oleh masyarakat Desa Carebbu, nilai-nilai tersebut berupa nilai hiburan yang menjadi perekat hubungan sosial pada masyarakat setempat, selanjutnya adalah nilai spiritual yang juga menjadi perekat dan penghubung manusia dan Tuhannya, dan yang terakhir adalah nilai-nilai kebersamaan dan kekeluargaan. Nilai- nilai yang terkandung di dalam pesta adat mappadekko tersebut memberikan pesan moral yan baik di dalam agama maupun adat istiadat bahwa sesuatu hal yang paling berharga dalam hidup ini adalah menjaga hubungan dengan Tuhan dan menjaga hubungan sesama manusia. 085399196684

\subsection{Pendekatan AGIL dalam Teori Sistem Sosial Tallcott Parson}

Hubungan AGIL dengan sistem pengetahuan lokal yang membentuk suatu sistem sebagai berikut. 


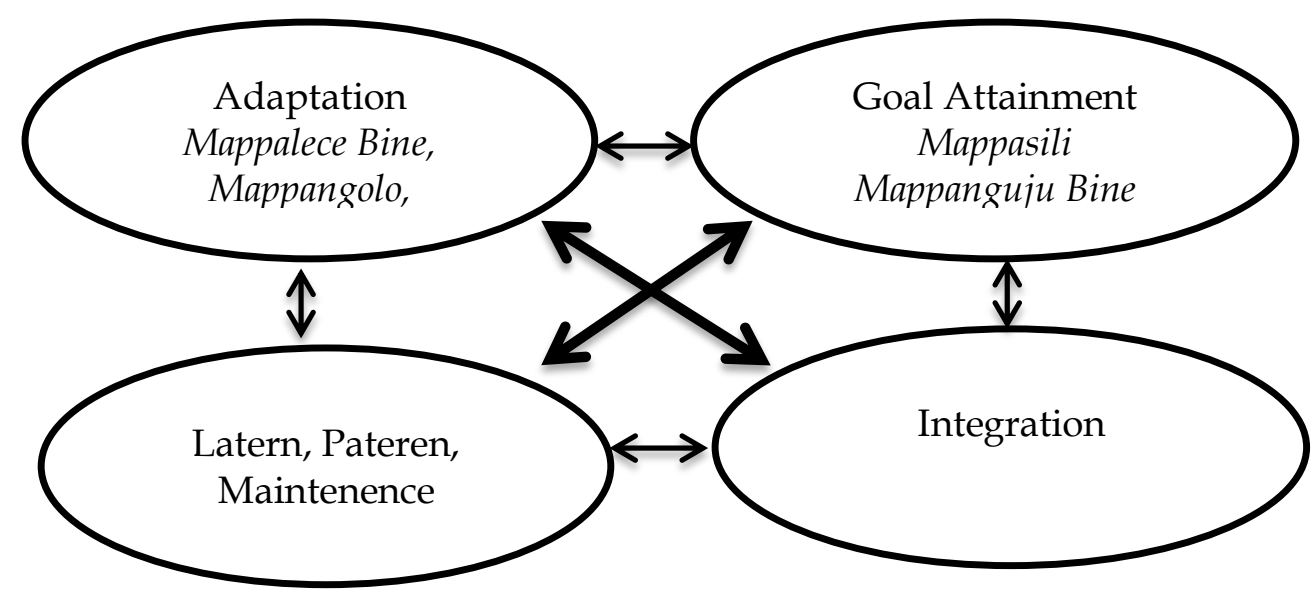

\section{Gambar 1. Hubungan AGIL dengan Sistem Pengetahuan Lokal Masyarakat Tani di Desa Carebbu.}

\subsection{Pengelolaan Pertanian di Era Revolusi Hijau}

Salah satu kegiatan revolusi hijau adalah intensifikasi pertanian. Intensifikasi dilakukan melalui pancausahatani yaitu pemilihan bibit unggul, pengolahan lahan dengan baik, pengairan, pemupukan, dan pemberantasan hama. Adapun fase dalam pengelolaan pertanian untuk budidaya tanaman padi di Desa Carebbu di era revolusi hijau ini adalah sebagai berikut.

Pemilihan Bibit Unggul. Para petani di Desa Carebbu masih bertahan menggunakan bibit lokal yang masa pertumbuhannya lebih lama yakni sekitar 6 bulan dibandingkan bibit unggul yang masa pertumbuhannya hanya sekitar 3 bulan saja. Para petani di Desa Carebbu masih bertahan menggunakan bibit lokal yang masa pertumbuhannya lebih lama yakni sekitar 6 bulan dibandingkan bibit unggul yang masa pertumbuhannya hanya sekitar 3 bulan saja.

Teknik Pengolahan Lahan Pertanian. Pada zaman yang makin maju ini, penggunaan rakkala (traktor tradisional), kerbau, dan bingkung (cangkul) sebagai alat untuk membalik tanah agar tanah menjadi gembur telah diganti dengan penggunaan traktor, meskipun masih ada sebagian kecil yang masih menggunakan alat-alat tersebut.

Pengaturan Irigasi. Penggunaan air oleh petani di Desa Carebbu belum cukup baik, hal ini dikarenakan para petani masih mengandalkan air hujan dalam musim penanamannya. Oleh karena itu, penanaman hanya dapat dilakukan 2 sampai 3 kali dalam setahun

Pemupukan. Penggunaan pupuk kimia oleh petani di Desa Carebbu terbilang cukup rendah dikarenakan penggunaan pupuk organik yang masih marak digunakan. Hal ini menunjukkan bahwa lahan di Desa Carebbu masih cukup sebaik karena belum tersentuh dengan kimia sepenuhnya.

Pemberantasan Hama. Untuk menanggulangi hama, gulma, dan penyakit, para petani di Desa Carebbu mengandalkan penggunaan pestisida. Sebagian besar petani masih menggunakan pestisida alami meskipun sebagian kecil sudah menggunakan pestida kimia. Pestisida alami ini dibuat sendiri oleh petani yang berasal dari bahan-bahan alami berupa tumbuh- tumbuhan.

Untuk menanggulangi hama, gulma, dan penyakit, para petani di Desa Carebbu mengandalkan penggunaan pestisida. Sebagian besar petani masih menggunakan pestisida alami meskipun sebagian kecil sudah menggunakan pestida 
kimia. Pestisida alami ini dibuat sendiri oleh petani yang berasal dari bahan-bahan alami berupa tumbuh- tumbuhan.

Dengan demikian bibit unggul dan bahan kimia yang menjadi dua input utama revolusi hijau masih belum dapat diterima sepenuhnya oleh masyarakat tani di Desa Carebbu. Hal ini menyebabkan pertanian di Desa Carebbu tidak tergantung pada hal tersebut.

\subsection{Keberadaan Pengetahuan Lokal di Era Revolusi Hijau}

Keberadaan pengetahuan lokal di tengah era revolusi hijau terlihat pada Tabel 9. Terdapat tiga alternatif interaksi yang berlangsung yakni pengetahuan lokal menolak revolusi hijau, pengetahuan lokal ditolak oleh revolusi hijau, dan pengetahuan lokal bersinergi dengan revolusi hijau.

Tabel 9. Keberadaan Pengetahuan Lokal Masyarakat Tani di Era Revolusi Hijau di Desa Carebbu, Kecamatan Awangpone, Kabupaten Bone, Provinsi Sulawesi Selatan, 2019.

\begin{tabular}{|c|c|c|c|c|}
\hline No. & Pengetahuan Lokal & $\begin{array}{c}\text { Menolak } \\
\text { Revolusi Hijau }\end{array}$ & $\begin{array}{l}\text { Ditolak oleh } \\
\text { Revolusi Hijau }\end{array}$ & $\begin{array}{c}\text { Pengtetahuan Lokal } \\
\text { Bersinergi dengan } \\
\text { Revolusi Hijau }\end{array}$ \\
\hline 1 & Mattanra Esso & $\ddot{u}$ & & \\
\hline \multirow{5}{*}{2} & \multirow{5}{*}{$\begin{array}{l}\text { Ma'doj } \\
\text { a Bine: } \\
\text { - Mappalece Bine } \\
\text { - Mappangolo } \\
\text { - Massure' }\end{array}$} & & & \\
\hline & & $\ddot{u}$ & & \\
\hline & & $\ddot{u}$ & & \\
\hline & & & $\ddot{u}$ & \\
\hline & & $\ddot{u}$ & & \\
\hline 3 & Mappanguju Bine & & & $\ddot{\mathbf{u}}$ \\
\hline 4 & Mangampo Bine & & & $\ddot{u}$ \\
\hline 5 & Massisi Bine & & & $\ddot{u}$ \\
\hline 6 & Mappalece Ase Lunrara & & $\ddot{u}$ & \\
\hline 7 & Mengala & & & $\ddot{u}$ \\
\hline 8 & Acara Mappadekko & & & $\ddot{u}$ \\
\hline
\end{tabular}

Sumber: Data Primer, 2019

\section{Kesimpulan}

Sistem pengetahuan lokal masyarakat tani di Desa Carebbu, Kecamatan Awangpone, Kabupaten Bone pada masa lalu berlangsung dalam bentuk berbagai aktivitas yang dibarengi dengan ritual yakni: (a) Mattanra Esso (Penentuan Hari Baik), (b) Ma'doja Bine (Begadang untuk Benih Padi) yang di dalamnya terdapat 4 rangkaian ritual yang terdiri atas Mappalece Bine (Merayu/Membujuk Benih), Mappangolo (Berdo'a), Massure' (Pembacaan Surat), dan Mappasili (Pembersihan/Pensucian), (c) Mappanguju Bine (Menyiapkan Benih), (d) Mangampo Bine (Menabur Benih), (3) Massisi Bine (Menanam Bibit), (f) Mappalece Ase Lunrara (Merayu Padi Hamil), (g) Mengala (Panen), dan (h) Acara Mappadekko (Pesta Panen).

Pengetahuan lokal merupakan alat kontrol dan satu kesatuan yang saling terkait dalam pendekatan AGIL, antara lain: (i) Adaptation (Adaptasi) : Mattanra Esso, Mappalece Bine, Mappangolo, dan Massure'; (ii) Goal Attainment (Pencapaian Tujuan): Mappasili dan Mappanguju bine; (iii) Integration (Integrasi) : Mangampo Bine, Massisi Bine, dan Mappalece Ase Lunrara; dan (iv) Latent Pattern Maintenance (PemeliharaanPola Latent) : Mattanra Esso, Mappangolo, Mengala, dan Mappadekko. 
Di era revolusi hijau, tidak dipungkiri bahwa keberadaan pengetahuan lokal masyarakat tani sudah mulai terkikis. Hal ini pula mulai terjadi di Desa Carebbu, dimana dari 11 sistem pengetahuan lokal masyarakat tani dalam mengolah usahatani padi terdapat 4 pengetahuan lokal yang menolak revolusi hijau, 2 pengetahuan lokal ditolak oleh revolusi hijau dan 5 pengetahuan lokal dapat bersinergi dengan revolusi hijau. Hal ini didasari oleh pemikiran masyarakat tani yang telah semakin rasional.

\section{Daftar Pustaka}

Ali, M. S. S., 2000. Pengetahuan Lokal dan Pembangunan Pertanian Berkelanjutan: Perspektif Dari Kaum Marjinal. Fakultas Pertanian dan Kehutanan Universitas Hasanuddin. Makassar.

Badan Pusat Statistik. 2017. Kabupaten Bone Dalam Angka 2013-2017. Kabupaten Bone.

Badan Pusat Statistik.

Basry, N., 2012. Eksistensi Pengetahuan Lokal Masyarakat Tani di Tengah Era Revolusi Hijau. Fakultas Pertanian Universitas Hasanuddin. Makassar.

Berkes, F. et.al., 1995. Traditional Ecological Knowledge, Biodiversity, Resiliece, and Sustainability, dalam Perring, C.A., et. al., 1995, Biodiversity Conversation. The Netherland. Kluwer Academic.

Husnah, N., M. S.S. Ali, D. Salman, P. Hijjang, F. Djufry, A. A. Amrawaty, 2015. Merging

Indigenous and Modern Knowledge in Agricultural Development. IJAS. Vol.2, Issue 2: 141-151.

Kamaluddin, A., A. Ala, M.S.S. Ali, D. Salman, 2012. The Adaptation of Rice Paddy Farmers Towards Climate Change. American-Eurasian Journal of Agricultural and Environmental Science. Vol. 12, Issue 7: 967-972.

Koentjaraningrat. 2009. Pengantar Ilmu Antropologi. Jakarta: PT. Rineka Cipta.

Mappangaja, A.R. 2009. Membangun Kapabilitas Menuju Pertanian Berkelanjutan. Fakultas

Pertanian Universitas Hasanuddin. Makassar.

Ritzer, G. dan G.J. Goodman. 2007. Teori Sosiologi Modern. Jakarta:Prenada Media Group.

Salman, D. 2012. Sosiologi Desa (Revolusi Senyap dan Tarian Kompleksitas). Makassar: Ininnawa.

Sugiyono. 2008. Metode Penelitian Kuantitatif dan Kualitatif. Bandung: CV.Alfabeta.

Sulkarnaen, A., 2017. Kelanjutan Tradisi Lisan Maddoja Bine Dalam Konteks Perubahan Sosial

Masyarakat Bugis. Fakultas Ilmu Pengetahuan Budaya Universitas Indonesia.

Depok. 
Syahruni. 2014. Perbandingan Budaya Bertani antara Komunitas Kajang Dalam dengan

Komunitas Kajang Luar (Studi Kasus Petani Padi Sawah di Desa Tanatoa, Kecamatan Kajang, Kabupaten Bulukumba, Provinsi Sulawesi Selatan). Fakultas Pertanian Universitas Hasanuddin. Makassar.

Wolf, E.R.. 1985. Petani: Suatu Tinjauan Antropologi. Jakarta: Penerbit CV. Rajawali. 
JSEP, Volume 16, No. 2, Juni 2020, Halaman 149 - 160 